Research Square $\quad \begin{aligned} & \text { Preprints are preliminary reports that have not undergone peer review. } \\ & \text { They should dot the considered conclusive, used to inform clinical practice, } \\ & \text { or referenenced by the medila as validated information. }\end{aligned}$

\title{
Efficient Degradation of Alginate And Preparation of Unsaturated Monosaccharides By A Novel Alginate Lyase And Effects of Domain Truncation On Biochemical Characteristics, Degradation Patterns
}

\author{
Qian Li \\ Nanjing Tech University \\ Shengsheng Cao \\ Nanjing Tech University \\ Ling Zheng \\ Nanjing Tech University \\ Benwei Zhu ( $\square$ zhubenwei@njtech.edu.cn ) \\ Nanjing Tech University
}

Research

Keywords: alginate, alginate lyase, molecular truncation, synergistic effect, biofuels

Posted Date: August 27th, 2021

DOI: https://doi.org/10.21203/rs.3.rs-832451/v1

License: @ (i) This work is licensed under a Creative Commons Attribution 4.0 International License. Read Full License 


\section{Abstract}

\section{Background}

Brown algae are considered promising crops for the production of sustainable biofuels. However, its commercial application has been limited by lack of efficient methods for converting alginate into fermentable sugars. Recently, exo-type alginate lyases have received extensive attention due to their excellent ability of conversion of alginate into 4-deoxy-L-erythro-5-hexoseulose uronate (DEH), a promising material for bioethanol production and biorefinery systems.

\section{Results}

Herein, we cloned and characterized a novel alginate lyase AlyPL17 from Pedobacter hainanensis NJ-02. It possessed outstanding catalytic efficiency towards polymannuronic acid (polyM), polyguluronic acid (polyG) and alginate sodium, with $k_{\text {cat }}$ of $39.42 \pm 1.9 \mathrm{~s}^{-1}$, $32.53 \pm 0.88 \mathrm{~s}^{-1}$, and $38.30 \pm 2.12 \mathrm{~s}^{-1}$, respectively. In addition, AlyPL17 adopts a unique hybrid action mode to degrade alginate by the synergistic effect of two domains. Furthermore, the combination of AlyPL17 and AlyPL6 exhibited apparently synergistic effect for the preparation of unsaturated monosaccharides.

\section{Conclusion}

Overall, the results show that AlyPL17 is a PL17 exo-type alginate lyase with high activity and a high conversion rate at low/moderate temperatures, which provides a useful enzymatic tool for the conversion of brown algae into biofuels and enhance our understanding of the function of modular domain of alginate lyase.

\section{Background}

With the global demand for renewable energy production increased markedly, methods for the production of bioethanol have been significantly improved in the past decade (Wargacki et al., 2012). Corn, sugarcane and several inedible lignocellulosic materials are preferable feedstocks (Takeda et al., 2011). However, it is difficult to convert the inedible lignocellulosic materials into unsaturated monosaccharides. In addition, using edible biomass could lead to bioethanol-food conflicts. Last but not least, large-scale cultivation of biofuel crops may lead to a net increase in greenhouse gases (Takeda et al., 2011). Requiring no arable land, and fresh water resources, marine algae has been considered as the third-generation feedstocks(Takeda et al., 2011).

The most abundant sugars in brown alga are alginate, mannitol and glucan ( such as cellulose and laminarin)(Enquist-Newman et al., 2014). In recent years, many researchers have developed various strategies for fermenting these sugars into bioethanol (Wargacki et al., 2012). However, the utilization of alginate for bioethanol production is still a major bottleneck. Alginate, an acidic polysaccharide, consists of $\beta$-D-mannuronic acid (M) and a-L-guluronic acid (G) (Zhu \& Yin, 2015). Several researchers have developed metabolic engineered microorganisms for fermenting alginate into ethanol. For example, Takeda et al. constructed a metabolically modified bacterium, Sphingomonas sp. A1, which could accumulate ethanol using alginate as the sole carbon source (Takeda et al., 2011). The metabolic pathway of alginate is as follows: firstly, endolytic alginate lyase could cleave the glycosidic bonds to create alginate oligosaccharides with various degrees of polymerization (Li et al., 2020), while exolytic lyase could release unsaturated monosaccharides or disaccharides as products (Tøndervik et al., 2010). Unsaturated monosaccharides could be converted into4- deoxyL-erythron-5-hexoseuloseuronate acid (DEH) through spontaneous conversion or KdgF catalysis (Hobbsa et al., 2017). Then DEH can be reduced to 2-keto-3-dexoxy-D-gluconate (KDG) before entering the Entner-Doudoroff (ED) pathway to produce two molecules of pyruvate, which may converted to two molecules of ethanol (Hobbsa et al., 2017) (Fig. 1). Thus, the degradation of alginate into unsaturated monosaccharides is an essential step for the preparation of bioethanol from alginate.

Various exolytic alginate lyases from several polysaccharide lyase families have been cloned and characterized in recent years. For instance, AlyGC (PL6 family) from Glaciecola chathamensis S18K6 ${ }^{\top}$ (Xu et al., 2017), VxAly7D (PL7 family) from Vibrio xiamenensis QY104 (Tang et al., 2020), Alg17c (PL17 family) from Saccharophagus degradans2-40 (Kim et al., 2012) and Atu3025 (PL15 family) from Agrobacterium tumefaciens (Ochiai et al., 2010). Nevertheless, most exolytic alginate lyases have low activity, resulting in low unsaturated monosaccharide yield. In addition, almost all of the alginate metabolic bacteria contain two or three putative alginate lyases with different action mode and substrate specificity (Li et al., 2018). However, complementary or synergistic effects of those alginate lyases have been rarely evaluated (Li et al., 2018). Thus, evaluating synergistic effects of the alginate lyase from the same bacteria, and establishing an efficient method for the production of unsaturated monosaccharides are urgent problems to be solved. 
In our previous work, we cloned and expressed a novel endolytic alginate lyase AlyPL6 from Pedobacterhainanensis NJ-02, which could degrade alginate into alginate oligosaccharides with high efficiency (Li et al., 2020). Herein, we cloned and characterized a new PL17 family alginate lyase AlyPL17 from the same bacteria. The biochemical characterization and action pattern of AlyPL17were investigated. Additionally, we initially explore the mechanism of action mode of this enzyme through domain truncation. We hypothesized that AlyPL6 and AlyPL17 exhibit better synergistic effects, and can degrade alginate completely. This study is expected to provide efficient enzyme for the degradation of alginate and production of biofuels.

\section{Results And Discussion}

\section{Sequence Analysis}

The open reading frame (ORF) of AlyPL17 consists of 2085bp encoded a putative alginate lyase composed of 695 amino acids with a theoretical molecular mass of $78.07 \mathrm{kDa}$. As shown in Fig. 2A, the full-length enzyme contains two domains, an alginate lyase domain (designed as AlyPL17-N, Lys $37-\mathrm{Gl}_{265}$ ) and a heparinase II/III-like domain (designed as AlyPL17-C, $\mathrm{Arg}_{357}-\mathrm{Phe}_{528}$ ). The phylogenetic tree was constructed and it exhibited AlyPL17 clusters with several alginate lyases of PL17 family. Based on the alignment of protein sequence, AlyPL17 has the highest sequence identity (45\%) with OAL from Stenotrophomonas maltophilia KJ-2 (GenBank accession no. AGM38186.2) (Shin et al., 2015), followed by Alg17c (44\%) from Saccharophagus degradans 2-40 (GenBank accession no. ABD82539.1) (Park et al., 2014). Furthermore, several key amino acid residues of PL17 family are highly conserved in AlyPL17 such as $\mathrm{N}_{177}, \mathrm{H}_{178}, \mathrm{Y}_{234}, \mathrm{Y}_{426}$ in active sites; $\mathrm{N}_{125}, \mathrm{R}_{236}, \mathrm{Y}_{237}, \mathrm{H}_{389}, \mathrm{R}_{414}$ in the substrate binding sites.

Based on the homologous structure of Alg17c (PDB: 4NEI) from Saccharophagus degradans 2-40, three-dimensional models of AlyPL17 and its truncated mutants were constructed by PHYRE2. The sequence identity between AlyPL17 and Alg17c was high (44\%). Accordingly, the protein model was successfully constructed with $100 \%$ confidence. As shown in Fig. 2B, AlyPL17 harbors two domains, AlyPL17-N is folded as a $(\alpha / a)_{6}$ toroid fold, and AlyPL17-C is folded as a $\beta$-sandwich jellyroll with two anti-parallel $\beta$ sheets (Fig. 2C, 2D).

\section{Expression and Purification of AlyPL17 and Its Truncated Mutants}

After heterologously expressed and purified, the recombinant AlyPL17, AlyPL17-N and AlyPL17-C were obtained and then analyzed by SDS-PAGE. In Fig. 3, three clear bands represented the molecular mass of purifiedAlyPL17, AlyPL17-N and AlyPL17-C can be observed, which are consistent with the predicted molecular mass of $78.07 \mathrm{kDa}, 39.22 \mathrm{kDa}$ and $39.78 \mathrm{kDa}$, respectively. The molecular mass (Mr) of other PL17 alginate lyases varied from $75 \mathrm{kDa}$ to $86 \mathrm{kDa}$. For example, OalB from Vibrio splendidus $12 \mathrm{~B} 01$ (Jagtap et al., 2014), Alg17c from Saccharophagus degradans 2-40 (Park et al., 2014) and Oal17A from Vibrio sp. W13 (Lyu et al., 2018) possess the molecular mass of $83 \mathrm{kDa}, 79 \mathrm{kDa}$ and $81 \mathrm{kDa}$, respectively.

Three different substrates ( $0.5 \%$ sodium alginate, $0.5 \%$ polyM and $0.5 \%$ polyG) were applied to determine the activities of AlyPL 17 and its truncated mutants. As shown in Table 1, the full-length enzyme AlyPL17 exhibited higher activities towards polyM $(861.62 \pm 1.53$ $\mathrm{U} / \mathrm{mg})$ than towards sodium alginate $(808.53 \pm 2.23 \mathrm{U} / \mathrm{mg})$, and polyG $(802.62 \pm 2.45 \mathrm{U} / \mathrm{mg})$. To the best of our knowledge, AlyPL17 has relatively higher enzymatic activities than most PL17 family alginate lyases. For instance, the activities of AlyPL17 towards sodium alginate, polyM and polyG are2.0, 1.71 and 3.97 times higher than the activities ofAlg17B(MacDonald et al., 2016). Moreover, the activities of AlgSH17 towards sodium alginate, polyM and polyG were $55.62 \mathrm{U} / \mathrm{mg}, 116.8 \mathrm{U} / \mathrm{mg}, 30.28 \mathrm{U} / \mathrm{mg}$, respectively, which are 14.53, 7.73 and 26.50 times lower than that of AlyPL17(Yang et al., 2021). Accordingly, AlyPL17wasanexcellent tool for the degradation of alginate. In contrast, two truncated mutants (AlyPL17-N and AlyPL17-C) maintained only 3-5\% of its initial activity. It indicates that both AlyPL17-N and AlyPL17-C domains were essential for maintaining activity. Furthermore, the $k_{\mathrm{m}}$ values of AlyPL17 with polyM, sodium alginate and polyG as substrates were $3.35 \pm 0.62,3.62 \pm 0.23$ and $4.89 \pm 0.71 \mathrm{mM}$, respectively. Thus, AlyPL17 was considered to prefer polyM block region in alginate polymer. Additionally, the $k_{\text {cat }}$ values of AlyPL17 towards polyM, sodium alginate and polyG were $39.42 \pm 1.69,38.30 \pm 2.12$ and $32.53 \pm 0.88 \mathrm{~s}^{-1}$, respectively. It suggests that AlyPL17was a novel alginate lyase specific for polyM. Similarly, most alginate lyases from the PL17 family were polyM-preferred lyases, such as OalC17 from Cellulophaga sp.SY116 (Wang et al., 2014), AlgL17 from Microbulbifersp. ALW1(Jiang et al., 2019), and Smlt2602 from Stenotrophomonas maltophilia K279a (MacDonald et al., 2016). 
Table 1

substrate specificity and kinetics of AlyPL17

\begin{tabular}{|llll|}
\hline Substrate & Sodium alginate & PolyM & PolyG \\
\hline Activity $(\mathrm{U} / \mathrm{mg})$ & $808.53 \pm 4.23$ & $861.62 \pm 3.53$ & $802.62 \pm 3.45$ \\
\hline$K_{\mathrm{m}}(\mathrm{mM})$ & $3.62 \pm 0.23$ & $3.35 \pm 0.62$ & $4.89 \pm 0.71$ \\
\hline $\mathrm{V}_{\mathrm{max}}(\mu \mathrm{mol} / \mathrm{s})$ & $9.96 \pm 0.95$ & $10.24 \pm 0.68$ & $8.45 \pm 1.02$ \\
\hline$k_{\text {cat }}\left(\mathrm{s}^{-1}\right)$ & $38.30 \pm 2.12$ & $39.42 \pm 1.69$ & $32.53 \pm 0.88$ \\
$k_{\text {cat }} / K_{\mathrm{m}}\left(\mathrm{s}^{-1} / \mathrm{mM}\right)$ & $10.58 \pm 2.15$ & $11.76 \pm 2.36$ & $6.65 \pm 0.77$ \\
\hline
\end{tabular}

\section{Biochemical Characterization of AlyPL17 and Its Truncated Mutants}

For biochemical characterization of AlyPL17, AlyPL17-Nand AlyPL17-C, both AlyPL17 and its truncated mutants exhibited the highest activities at $45^{\circ} \mathrm{C}$ (Fig. 4A) and pH 9.0 (Fig. 4D). As shown in Table 2, the optimal reaction conditions of alginate lyases from PL17 family are in the range of 30 to $50^{\circ} \mathrm{C}$, and pH 6.0 to 8.0. For example, OalS17 (Wang et al., 2014) from Shewanella sp. Kz7 showed the highest activity at $50^{\circ} \mathrm{C}$ and $\mathrm{pH} 6.2$, and TcAlg1 from Thalassotalea crassostreae exhibited the maximal activity at $40^{\circ} \mathrm{C}$ and $\mathrm{pH} 7.0$ (Wang et al., 2018). Moreover, the optimal temperature and pH of Oalv17 were $40^{\circ} \mathrm{C}$ and 7.2(Li et al., 2020), respectively. In terms of temperature stability, AlyPL17 retains about $40 \%$ activityafter being incubated at $40^{\circ} \mathrm{C}$ for $1 \mathrm{~h}$ (Fig. $4 \mathrm{~B}$ ), which was better than several PL17 family alginate lyases. For instance, OalC17 retains $20 \%$ of maximal activity after being incubated at $40^{\circ} \mathrm{C}$ for $1 \mathrm{~h}$ ( $\mathrm{Li}$ et al., 2018 ), and AlgSH17 could only retain stability at $20-25^{\circ} \mathrm{C}$ (Yang et al., 2021). Interestingly, the two truncated mutants exhibited excellent thermal stability, AlyPL17-N and AlyPL17-C could retain about $95 \%$ and $80 \%$ of its maximal activities after being incubated at $40^{\circ} \mathrm{C}$ for 1 h (Fig. 4C). This phenomenon was also shown in truncated mutant Aly7B-CDIl, which exhibited greater temperature stability than fulllength enzyme Aly7B at $35^{\circ} \mathrm{C}(\mathrm{Hu}$ et al., 2019). Similarly, the thermal ability of truncated AlgH-I and AlgH-II are 2.1 and 1.3-fold higher than full-length enzyme AlgH (Yan et al., 2019). Perhaps the truncated mutants have a more compact structure than full-length enzyme and thereby resists the effects of thermal degeneration (Hu et al., 2019). AlyPL17 reserves more than $60 \%$ of its maximal activities after being incubated at pH 6.0-9.0 for $24 \mathrm{~h}$. Whereas, AlyPL17-N and AlyPL17-C maintained better stability at pH 9.0 (Fig. 4E). In further characterization, we introduced various metal ions to explore the effects on enzymatic activity. As shown in Fig. 4F, AlyPL17 was activated by $\mathrm{Mg}^{2+}$ and $\mathrm{Mn}^{2+}$. Moreover, AlyPL17-N could be activated by $\mathrm{Na}^{+}$. In addition, $\mathrm{Co}^{2+}, \mathrm{Zn}^{2+}, \mathrm{Cu}^{2+}$ and Fe ${ }^{3+}$ can inhibit the activities of AlyPL17 and its truncated mutants, as known for many other alginate lyases from PL17 Family.

Table 2 Characteristics of alginate lyases from PL17 family 


\begin{tabular}{|c|c|c|c|c|c|c|}
\hline Enzyme & $\begin{array}{l}\text { Action } \\
\text { mode }\end{array}$ & $\begin{array}{l}\text { Optimal } \\
\text { temperature/pH }\end{array}$ & $\begin{array}{l}\text { Temperature/pH } \\
\text { stability }\end{array}$ & $\begin{array}{l}\text { Substrate } \\
\text { preference }\end{array}$ & Source & Reference \\
\hline \multirow[t]{2}{*}{ AlyPL17 } & endo+exo & $45^{\circ} \mathrm{C} / 9.0$ & $\begin{array}{l}35^{\circ} \mathrm{C}, 60 \mathrm{~min} \\
\text { remained } 97 \% \text {; }\end{array}$ & polyM & Pedobacter hainanensis NJ-02 & This study \\
\hline & & & $\begin{array}{l}\mathrm{pH} 6.0-9.0,24 \mathrm{~h} \\
\text { remained } 60 \%\end{array}$ & & & \\
\hline Oal17A & exo & $30^{\circ} \mathrm{C} / 7.0$ & $\begin{array}{l}45^{\circ} \mathrm{C}, \mathrm{pH} 6.0- \\
9.0 \text {, remained } \geq \\
80 \%\end{array}$ & polyMG & Vibrio sp. W13 & $\begin{array}{l}\text { (Lyu et al., } \\
\text { 2018) }\end{array}$ \\
\hline \multirow[t]{2}{*}{ Oalv17 } & exo & $40^{\circ} \mathrm{C} / 7.2$ & $\begin{array}{l}40^{\circ} \mathrm{C}, 60 \mathrm{~min}, \\
\text { remained } 74.5 \% \text {; }\end{array}$ & polyM & Vibrio sp. SY01 & $\begin{array}{l}\text { (Li et al., } \\
\text { 2020) }\end{array}$ \\
\hline & & & $\begin{array}{l}\mathrm{pH} 3.4-8.0,12 \mathrm{~h} \\
\text { remained } 70 \%\end{array}$ & & & \\
\hline OalB & exo & $30^{\circ} \mathrm{C} / 7.0$ & NA & polyMG & Vibrio splendidus12B01 & $\begin{array}{l}\text { (Jagtap et } \\
\text { al., 2014) }\end{array}$ \\
\hline OalC & exo & $35^{\circ} \mathrm{C} / 7.5$ & NA & polyM & Vibrio splendidus12B01 & $\begin{array}{l}\text { (Jagtap et } \\
\text { al., 2014) }\end{array}$ \\
\hline $\mathrm{OAL}$ & endo+exo & $37^{\circ} \mathrm{C} / 7.5$ & NA & polyM & $\begin{array}{l}\text { StenotrophomonasmaltophiliaKJ- } \\
2\end{array}$ & $\begin{array}{l}\text { (Shin et al., } \\
\text { 2015) }\end{array}$ \\
\hline Alg17C & exo & $40^{\circ} \mathrm{C} / 6.0$ & NA & $\begin{array}{l}\text { polyM, } \\
\text { polyG }\end{array}$ & Saccharophagus degradans 2-40 & $\begin{array}{l}\text { (Park et al., } \\
\text { 2014) }\end{array}$ \\
\hline \multirow[t]{2}{*}{ Alg17B } & endo+exo & $45^{\circ} \mathrm{C} / 7.5-8.0$ & $\begin{array}{l}40^{\circ} \mathrm{C}, 60 \mathrm{~min} \\
\text { remained } 40 \% \text {; }\end{array}$ & $\mathrm{Bi}-$ & Vibriosp.BP-2 & $\begin{array}{l}\text { (Huang et } \\
\text { al., 2019) }\end{array}$ \\
\hline & & & $\begin{array}{l}\mathrm{pH} 6.5-8.0,24 \mathrm{~h} \\
\text { remained } 75 \%\end{array}$ & & & \\
\hline FIAlyB & exo & NA & NA & polyM & Flavobacterium sp. strain UMI-01 & $\begin{array}{l}\text { (Nishiyama } \\
\text { et al., 2017) }\end{array}$ \\
\hline TcAlg1 & exo & $40^{\circ} \mathrm{C} / 7.0$ & $\begin{array}{l}40^{\circ} \mathrm{C}, 60 \mathrm{~min}, \\
\text { remain } \\
\text { unchanged }\end{array}$ & polyM & Thalassotalea crassostreae & $\begin{array}{l}\text { (Wang et al., } \\
\text { 2018) }\end{array}$ \\
\hline \multirow[t]{2}{*}{ OalS17 } & exo & $50^{\circ} \mathrm{C} / 6.2$ & $\begin{array}{l}40^{\circ} \mathrm{C}, 60 \mathrm{~min}, \\
\text { remained } 88 \%\end{array}$ & polyMG & Shewanella sp. Kz7 & $\begin{array}{l}\text { (Wang et al., } \\
\text { 2014) }\end{array}$ \\
\hline & & & $\begin{array}{l}\mathrm{pH} 6.0-9.0,6 \mathrm{~h}, \\
\text { remained stable }\end{array}$ & & & \\
\hline AlgL & endo+exo & $50^{\circ} \mathrm{C} / 6.5$ & NA & polyM & Sphingomonas sp. MJ-3 & $\begin{array}{l}\text { (Jiang et al., } \\
\text { 2019) }\end{array}$ \\
\hline \multirow[t]{2}{*}{ OalC17 } & exo & $50^{\circ} \mathrm{C} / 7.2$ & $\begin{array}{l}40^{\circ} \mathrm{C}, 60 \mathrm{~min} \\
\text { remained } 20 \% \text {; }\end{array}$ & polyM & Cellulophaga sp.SY116 & $\begin{array}{l}\text { (Li et al., } \\
\text { 2018) }\end{array}$ \\
\hline & & & $\begin{array}{l}\mathrm{pH} 6.0-8.0,6 \mathrm{~h}, \\
\text { remained } 85 \%\end{array}$ & & & \\
\hline Smlt2602 & exo & $-/ 8.5$ & NA & polyM & $\begin{array}{l}\text { Stenotrophomonas maltophilia } \\
\text { K279a }\end{array}$ & $\begin{array}{l}\text { (MacDonald } \\
\text { et al., 2016) }\end{array}$ \\
\hline AlgSH17 & endo+exo & $30^{\circ} \mathrm{C} / 7.0$ & $\begin{array}{l}40^{\circ} \mathrm{C}, 60 \mathrm{~min}, \\
\text { remained less } \\
\text { than } 20 \% \text {; } \\
\mathrm{pH} 6.0-8.0,2 \mathrm{~h} \text {, } \\
\text { remained } 80 \%\end{array}$ & polyM & Microbulbifer sp. SH- 1 & $\begin{array}{l}\text { (Yang et al., } \\
2021 \text { ) }\end{array}$ \\
\hline
\end{tabular}




\section{Analysis of Action Pattern and Degradation Products of AlyPL17 and Its Truncated Mutants}

Degradation products of AlyPL17 and its truncated mutants towards sodium alginate at various times $(0-48 \mathrm{~h})$ were analyzed by Fast protein liquid chromatography (FPLC). As shown in Fig. 5A, at preliminary stage of reaction, AlyPL17 could degrade alginate into dimers and monosaccharides. However, dimers were degraded into monosaccharides after incubation for $48 \mathrm{~h}$. In accordance with the results above, AlyPL17 adopts a unique action mode that combines the endolytic action pattern and exolytic action pattern. ESI-MS was used to analyze the composition of the end products (Fig. $6 \mathrm{~A}$ ), one molecular ion peak at $175.02 \mathrm{~m} / \mathrm{z}[\Delta \mathrm{DP} 1-\mathrm{H}]^{-}$was individually detected in the corresponding fraction. As shown in Table 2, although most alginate lyases from thePL 17 family adopt exolytic mode to degrade alginate such asOalC17 from Cellulophaga sp.SY116 (Li et al., 2018)and FIAlyB from Flavobacterium sp. strain UMI-01(Nishiyama et al., 2017). This unique hybrid action pattern also has been adopted by several alginate lyases of PL17 family. For example, Alg17B from BP2 (new species) could degrade alginate into alginate oligosaccharides with DP1-6 at preliminary stage of reaction, and then degrade alginate oligosaccharides into disaccharides and monosaccharides (Huang et al., 2019). Moreover, in the early stages of the reaction, OAL from StenotrophomonasmaltophiliaKJ-2 could produce alginate oligosaccharides with DP 1-4, and gradually degrade oligosaccharide into monosaccharide. Furthermore, AlgL from Sphingomonas sp. MJ-3 degrades alginate into alginate oligosaccharides with DP2-4 in endolytic action mode, and then it could degrade alginate oligosaccharides into monosaccharide in exolytic action mode (Jiang et al., 2019). Additionally, AlgSH17 from Microbulbifersp. SH-1 also possesses both endolytic and exolytic activity (Yang et al., 2021). To explore the functions of the two domains, we analyzed the products distribution of AlyPL17-N and AlyPL17-C.As shown in Fig. 5B, AlyPL17-N exhibited a typical endolytic action pattern, which could degrade alginate into dimers, trimers, and tetramers. The final products had three molecular ion peaks at $268.79 \mathrm{~m} / z$ [DP3 $+\mathrm{H}_{2} \mathrm{O}-\mathrm{H}^{2-}{ }^{2-}, 351.72 \mathrm{~m} / z$ [DP2-H] $]^{-}, 657.98 \mathrm{~m} / \mathrm{z}$ [DP4 + 4H-3Na] ${ }^{-}$(Fig. 6B). In addition, AlyPL17-C also showed endolytic degradation mode towards sodium alginate(Fig. $5 \mathrm{C}$ ), and the main products of AlyPL17Cwere oligosaccharide with DP1-4(Fig. 6C). The final products had four molecular ion peaks at $160.84 \mathrm{~m} / \mathrm{z}\left[\Delta-\mathrm{H}_{2} \mathrm{O}+3 \mathrm{H}\right]^{2-}, 268.79 \mathrm{~m} / \mathrm{z}$ [DP3 $\left.+\mathrm{H}_{2} \mathrm{O}-\mathrm{H}\right]^{2-}, 351.72 \mathrm{~m} / \mathrm{z}$ [DP2-H] $]^{-}, 657.98 \mathrm{~m} / \mathrm{z}$ [DP4 + 4H-3Na] ${ }^{-}$(Fig. 6C). Similarly, the two truncated mutants of OAL adopt endolytic action mode to degrade alginate, and the main products of the mutants are DP1-6 (Shin et al., 2015). The hybrid activity of AlyPL17 perhaps is caused by the synergistic effects of AlyPL17-N and AlyPL17-C.

\section{Synergistic Effect of AlyPL17 and AlyPL6}

Although AlyPL17 exhibited relatively higher activities towards alginate than most of alginate lyases from PL17 family, it still showed lower catalysis efficiency than most endolytic alginate lyases. In our previous work, we cloned and characterized a novel endolytic alginate lyase AlyPL6 with high activity from Pedobacter hainanensis NJ-02 (Li et al., 2020). Since AlyPL17 has the ability to degrade alginate oligosaccharides into monosaccharide, it may prefer digesting the oligosaccharides with low DPs. Additionally, AlyPL17 and AlyPL6 were isolated from the same strain and have similar optimal reaction conditions. Last but not least, AlyPL17 and AlyPL6 have the complementary substrate specificity, AlyPL6 was polyMG preferred alginate lyase, and AlyPL17 exhibited the highest activities towards polyM. Therefore, AlyPL6and AlyPL17 may exhibit a synergistic degradation effect towards alginate. To investigate this possibility, the enzymatic assay was applied to evaluate the catalytic ability of AlyPL6 plus AlyPL17 (AlyPL6/AlyPL17 ratio: 0, 1:9, 2:8, $3: 7,4: 6$, and 5:5).

As shown in Supplementary Table S1, as the percentage of AlyPL6 goes up, the activities towards alginate have been improved obviously. When the ratio of AlyPL6/AlyPL17 reaches 4:6, the degradation activity towards alginate reached the maximum. Furthermore, in order to compare the monosaccharide yield of AlyPL6 plus AlyPL17 (AlyPL6/AlyPL17 ratio: 4:6) and AlyPL17 alone, FPLC was used

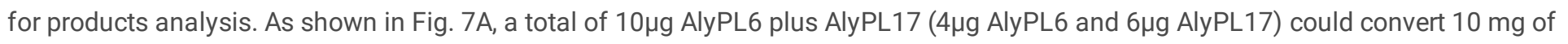
alginate into unsaturated monosaccharide with a yield of $21.4 \%$ after being incubated $10 \mathrm{~min}$. In addition, the monosaccharides yield of AlyPL6 plus AlyPL17 (45\%) was 1.96 times higher than AlyPL17 (23\%) after being incubated at $45^{\circ} \mathrm{C}$ for 1h (Fig. 7B). Similarly, Li et al. established the method for the production of monosaccharide by combining endolytic alginate lyase AlySY08 and exolytic alginate lyases (OalC6 and OalC17) (Li et al., 2018). However, the activities and the temperature stabilities of OalC6 and OalC17 are weaker than AlyPL6 and AlyPL17 (Li et al., 2018). Accordingly, the combination of AlyPL6 and AlyPL17 is an efficient and stable tool for the production of biofuels from alginate.

\section{Conclusion}

In conclusion, a novel PL17 family AlyPL17 from Pedobacter hainanensis NJ-02 was cloned and expressed. Its biochemical properties and action pattern were clarified. Furthermore, to investigate the function of the two domains, the N-terminal domain (AlyPL17-N) and Cterminal (AlyPL17-C) domain of AlyPL17 were subcloned and expressed, independently. AlyPL17 shared the highest identity of $45 \%$ with 
$\mathrm{OAL}$ and showed optimal activity at $45^{\circ} \mathrm{C}$ and $\mathrm{pH}$ 9.0. Compared with other alginate lyases from the PL17 family, AlyPL17 has relatively high activity. Nevertheless, two truncated mutants AlyPL17-N and AlyPL17-C showed decreased activities, which indicated that both AlyPL17-N and AlyPL17-C domains are essential to maintain high activity of the full-length enzyme. AlyPL17 could degrade alginate into monosaccharide by a hybrid action mode that combined the endolytic action pattern and exolytic action pattern. However, AlyPL17-N and AlyPL17-Cexhibited an endolytic action pattern towards alginate. It suggested that AlyPL17-N and AlyPL17-C might show a synergistic effect, resulting in high exolytic activity of full-length enzyme AlyPL17. Last but not least, AlyPL6 and AlyPL17 exhibit excellent synergistic effects. When AlyPL6 and AlyPL17 were combined in a ratio of 4:6, the unsaturated monosaccharide conversion rate reached $45 \%$ in one hour. This work provides efficient enzymes for the development of biofuels from marine brown algae.

\section{Materials And Methods}

\section{Materials and Strains.}

Sodium alginate from Macrosystis pyrifera was purchased from Sigma-Aldrich (M/G ratio 77/23, viscosity $\geq 2000 \mathrm{Cp}$, St. Louis, MO, USA). PolyM and polyG (purity: about 95\%, M/G ratio: $97 / 3$ and 3/97, respectively) were purchased from Qingdao BZ Oligo Biotech Co., Ltd. (Qingdao, China). Pedobacter hainanensis NJ-02(CCTCC M2016579) was isolated from the East China Sea and conserved in our laboratory. E. coli BL21 (DE3) was used for gene expression and was grown in Luria-Bertani (LB) broth or on LB broth agar plates (LB broth supplemented with $1.0 \%$ agar) including $100 \mathrm{mg} / \mathrm{mL}$ ampicillin.

\section{Sequence Analysis}

The conserved domains of AlyPL17 were predicted using the NCBI database by the CD-search application (https://www.ncbi.nlm.nih.gov/Structure/cdd/wrpsb.cgi). The vector-NTI (Life Technologies, Grand Island, NY) was used for homology analysis of protein sequence. The phylogenetic tree was constructed according to the relative protein sequences of PL17 family through molecular evolutionary genetics analysis (MEGA) program version 6.0. According to the structure of alginate lyase Alg17c from Saccharophagus degradans 2-40 (PDB: 4NEI), the three-dimensional structure of AlyPL17, AlyPL17N and AlyPL17C were constructed through Homology/analogY Recognition Engine V 2.0.The final structures of AlyPL17 and its truncated mutants were viewed in the PyMOL software.

\section{Heterologous Expression and Purification of Recombinant Alginate Lyase}

The genes ofAlyPL17, AlyPL17-N and AlyPL17-C were synthesized by GENEWIZ (Suzhou, Jiangsu province, China). These three genes were ligated into pET-21a (+) expression vector and were then transformed into E. coli BL21 (DE3). All recombinant strains were cultured and induced as previously reported(Zhu et al., 2019a). After culturing cells at $22^{\circ} \mathrm{C}$ for $36 \mathrm{~h}$, the AlyPL17, AlyPL17-N and AlyPL17-C were purified by Ni-NTA sepharose column (GE Healthcare, Uppsala, Sweden) and HiTrap ${ }^{\mathrm{TM}}$ desalting column (Amersham Biosciences, Buckinghamshire, UK) (Hu et al., 2019). Sodium dodecylsulfate polyacrylamide gel electrophoresis (SDS-PAGE) was applied to analyze the purity of the recombinant proteins. Furthermore, the protein quantitative analysis kit (Beyotime Institute of Biotechnology, Nantong, China) was used to determine the concentration of recombinant proteins.

\section{Substrate Specificity and Enzymatic Kinetics}

The activities of AlyPL17and its two truncated mutants were investigated using the ultraviolet absorption method described by Inoue (Zhu et al., 2019).20mL purified recombinant proteins were incubated with $180 \mathrm{~mL} 0.5 \%(\mathrm{w} / \mathrm{v})$ substrates (sodium alginate, polyM and poly dissolved in $50 \mathrm{mM}$ glycine- $\mathrm{NaOH}$ buffer $\mathrm{pH} 9.0$ ) at $45^{\circ} \mathrm{C}$ for $10 \mathrm{~min}$. One-unit enzymatic activity was defined as the amount of enzyme required to increase the absorbance at $235 \mathrm{~nm}$ (extinction coefficient: $6150 \mathrm{M}^{-1} \cdot \mathrm{cm}^{-1}$ ) by 0.1 per min. The kinetic parameters of AlyPL17 towards different substrates were studied through measuring activities with substrates at different concentrations (0.4-4 $\mathrm{mg} / \mathrm{mL})$. Velocity $(V$ at different substrate concentrations was calculated as follows: $\mathrm{V}(\mathrm{mol} / \mathrm{s})=(\mathrm{milliAU} / \mathrm{min} \times \mathrm{min} / 60 \mathrm{~s} \times \mathrm{AU} / 1000$ milliAU $\times 1 \mathrm{~cm}) /\left(6150 \mathrm{M}^{-1} \mathrm{~cm}^{-1}\right) \times\left(2 \times 10^{-4} \mathrm{~L}\right)\left(\right.$ Zhu et al., 2019). The $K_{\mathrm{m}}, V_{\max }$ values of AlyPL17 were calculated by hyperbolic regression analysis as previously reported (Li et al., 2020). The radio of $V_{\max }$ versus enzyme concentration ([E]) was used to calculate the turnover number $\left(k_{\text {cat }}\right)$ of the enzyme.

\section{Biochemical Characterization of AlyPL17 and Its Truncated Mutants}


To determine the optimal temperature and the thermal stability of AlyPL17, AlyPL17-N and AlyPL17-C, reactions were carried out at $30^{\circ} \mathrm{C}-$ $55^{\circ} \mathrm{C}$. Additionally, the thermally induced denaturation was also investigated by evaluating the residual activities after incubating at $40-$ $45^{\circ} \mathrm{Cfor}$ 0-60 min. The influence of $\mathrm{pH}$ on enzymatic activities of these enzymes was studied by measuring the activities in presence of different buffers (50mM phosphate-citrate ( $\mathrm{pH} 4.0-5.0), 50 \mathrm{mM} \mathrm{NaH}_{2} \mathrm{PO}_{4}-\mathrm{Na}_{2} \mathrm{HPO}_{4}(\mathrm{pH} 6.0-8.0), 50 \mathrm{mM}$ Tris- $\mathrm{HCl}(\mathrm{pH} 7.0-9.0)$ and 50 $\mathrm{mM}$ glycine- $\mathrm{NaOH}$ ( $\mathrm{pH}$ 9.0-10.0)). Moreover, the $\mathrm{pH}$ stability was determined through assessing the residual activities after being incubated in different $\mathrm{pH}$ buffers at $4^{\circ} \mathrm{C}$ for $24 \mathrm{~h}$. Furthermore, to investigate the effects of metal ions on enzymatic activities, purified enzymes were incubated with various metal ions $(1 \mathrm{mM})$ at $4^{\circ} \mathrm{C}$ for $4 \mathrm{~h}$. The reaction mixture without any metal ions was regarded as control (100\% relative activity). In order to ensure the accuracy of the experiments, all experiments were performed with three replicates.

\section{Action Pattern and Degradation Products Analysis}

In order to explore the action pattern and degradation products of AlyPL17and its truncated mutants, $50 \mathrm{~mL}$ purified enzymes (10 mg) were incubated with $450 \mathrm{~mL} 0.5 \%$ sodium alginate at $40^{\circ} \mathrm{C}$ for $0-48 \mathrm{~h}$. The samples were taken after reaction for $1,8,24,48 \mathrm{~h}$, respectively. Fast protein liquid chromatography equipped with superdex peptide 10/300 GE Column (GE Health) was applied to analyze the degradation products of AlyPL17 and its two truncated mutants as previously reported (Li et al., 2020). In addition, the end products of AlyPL17 and its truncated mutants were analyzed by ESI-MS in a positive-ion mode using the following settings: ion source voltage, $4.5 \mathrm{kV}$; capillary temperature, $275-300^{\circ} \mathrm{C}$; Tube lens, $250 \mathrm{~V}$; sheath gas, 30 arbitrary units (AU); scanning mass range, $150-2000 \mathrm{~m} / \mathrm{z}$.

\section{Analysis of the Synergistic Effect of AlyPL17 and AlyPL6}

To investigate the optimal synergistic degradation ratio, 20mL AlyPL6 plus AlyPL17 (0.2 mg/mL, AlyPL6/AlyPL17 ratio:0, 1:9, 2:8, 3:7, 4:6, and 5:5) were added to $180 \mathrm{~mL}$ alginate $\left(5 \mathrm{mg} / \mathrm{mL}\right.$ in $50 \mathrm{mM}$ glycine-NaOH buffer pH 9.0) and incubated at $45^{\circ} \mathrm{C}$ for $10 \mathrm{~min}$. Ultraviolet absorption method was applied to measure the activity ofAlyPL6 plus AlyPL17. Furthermore, the composition of end products of optimal synergistic degradation ratio were analyzed by FPLC as previously reported (Li et al., 2020).

\section{Declarations}

\section{Ethics approval and consent to participate}

Not applicable.

\section{Consent for publication}

Not applicable.

\section{Competing interests}

The authors declare that they have no competing interests.

\section{Funding}

The work was supported by the National Natural Science Foundation of China (Grant Nos. 31601410), The Suqian City Science and Technology Project (L201906), Postgraduate Research \& Practice Innovation Program of Jiangsu Province (KYCX20_1103).

\section{Authors' contributions}

QL and SSC done the experiment and collected the data, QL, SSC and ZL wrote the manuscript, and ZBW revised this work. All authors read and approved the manuscript.

\section{Acknowledgements}

The work was supported by the National Natural Science Foundation of China (Grant Nos. 31601410), The Suqian City Science and Technology Project (L201906), Postgraduate Research \& Practice Innovation Program of Jiangsu Province (KYCX20_1103). Dr. Zhu Benwei gratefully acknowledges the support of Jiangsu Overseas Visiting Scholar Program for University Prominent Young and Midaged Teachers and Presidents.

\section{Availability of data and material}


Not applicable.

\section{Supporting information}

Nucleotide sequence of AlyPL17 and the parameter of synergistic reaction of AlyPL6 and AlyPL17 as deposited additional files.

\section{References}

1. Enquist-Newman M, Faust AME, Bravo DD, Santos CNS, Raisner RM, Hanel A, et al. Efficient ethanol production from brown macroalgae sugars by a synthetic yeast platform. Nature. 2014;505:239-43.

2. Hobbsa JK, Leea SM, Robba M, Hofb F, Barrb C, Abea KT, et al. KdgF, the missing link in the microbial metabolism of uronate sugars from pectin and alginate. Proc Natl Acad Sci USA. 2017;113:6188-93.

3. Hu F, Li Q, Zhu B, Ni F, Sun Y, Yao Z. Effects of module truncation on biochemical characteristics and products distribution of a new alginate lyase with two catalytic modules. Glycobiology. 2019;29:876-84.

4. Huang G, Wen S, Liao S, Wang Q, Pan S, Zhang R, et al. Characterization of a bifunctional alginate lyase as a new member of the polysaccharide lyase family 17 from a marine strain BP-2. Biotechnol Lett. 2019;41:1187-200.

5. Jagtap SS, Hehemann JH, Polz MF, Lee JK, Zhaob H. (2014). Comparative Biochemical Characterization of Three Exolytic Oligoalginate Lyases from Vibrio splendidus Reveals Complementary Substrate Scope, Temperature, and pH Adaptations. Applied and Environmental Microbiology, 80.

6. Jiang Z, Guoa Y, Wanga X, Lie H, Ni H, Li L, et al. Molecular cloning and characterization of AlgL17, a new exo-oligoalginate lyase from Microbulbifersp. ALW1. Protein Expr Purif. 2019;161:17-27.

7. Kim HT, Chung JH, Wang D, Lee J, Woo HC, Choi I-G, et al. Depolymerization of alginate into a monomeric sugar acid using Alg17C, an exo-oligoalginate lyase cloned from Saccharophagus degradans 2-40. Applied Microbiol Biotechnol. 2012;93:2233-9.

8. Li Q, Hu F, Wang M, Zhu B, Ni F, Yao Z. Elucidation of degradation pattern and immobilization of a novel alginate lyase for preparation of alginate oligosaccharides. Int J Biol Macromol. 2020;146:579-87.

9. Li S, Wang L, Chen X, Zhao W, Sun M, Han Y. Cloning, Expression, and Biochemical Characterization of Two New Oligoalginate Lyases with Synergistic Degradation Capability. Mar Biotechnol. 2018;20:75-86.

10. Li S, Wang L, Jung S, Lee BS, He N, Lee MS. (2020). Biochemical Characterization of a New Oligoalginate Lyase and Its Biotechnological Application in Laminaria japonica Degradation. Frontiers in Microbiology, 11.

11. Lyu Q, Zhang K, Zhu Q, Li Z, Liu Y, Fitzek E, et al. Structural and biochemical characterization of a multidomain alginate lyase reveals a novel role of CBM32 in CAZymes. Biochim Biophys Acta Gen Subj. 2018;9:1862-9.

12. MacDonald LC, Weiler EB, Berger BW. (2016). Engineering broad-spectrum digestion of polyuronides from an exolytic polysaccharide lyase. Biotechnology for Biofuels, 9.

13. Nishiyama R, Inoue A, Ojima T. (2017). Identification of 2-keto-3-deoxy-D-Gluconate Kinase and 2-keto-3-deoxy-D-Phosphogluconate Aldolase in an Alginate-Assimilating Bacterium, Flavobacterium sp. Strain UMI-01. Marine drugs, 15.

14. Ochiai A, Yamasaki M, Mikami B, Hashimoto W, Murata K. Crystal Structure of Exotype Alginate Lyase Atu3025 from Agrobacterium tumefaciens. Thejournalofbiologicalchemistry. 2010;285:24519-28.

15. Park D, Jagtap S, Nair SK. Structure of a PL17 Family Alginate Lyase Demonstrates Functional Similarities among Exotype Depolymerases. The Journalof Biological Chemistry. 2014;289:8645-55.

16. Shin JW, Lee OK, Park HH, Kim HS, Lee EY. Molecular characterization of a novel oligoalginate lyase consisting of AlgL-and heparinase II/III-like domains from Stenotrophomonas maltophilia KJ-2 and its application to alginate saccharification. Korean $\mathrm{J}$ Chem Eng. 2015;32:917-24.

17. Shin JW, Lee OK, Park HH, Kim HS, Lee.(2015). Molecular characterization of a novel oligoalginate lyase consisting of AlgL-and heparinase II/III-like domains from Stenotrophomonas maltophilia KJ-2 and its application to alginate saccharification. 32, 917924.

18. Takeda H, Yoneyama F, Kawai S, Hashimoto W, Murata K. Bioethanol production from marine biomass alginate by metabolically engineered bacteria. Energy Environ Sci. 2011;4:2575-81.

19. Tang L, Wang Y, Gao S, Wu H, Wang D, Yu W, et al. (2020). Biochemical characteristics and molecular mechanism of an exo-type alginate lyase VxAly7D and its use for the preparation of unsaturated monosaccharides. Biotechnology for Biofuels, 13. 
20. Tøndervik A, Klinkenberg G, Aarstad OA, Drabløs F, Ertesvåg H, Ellingsen TE, et al. Isolation of Mutant Alginate Lyases with Cleavage Specificity for Di-guluronic Acid Linkages. J Biol Chem. 2010;285:35284-92.

21. Wang D, Aarstad OA, Li J, McKee LS, Sætrom GI, Vyas A, et al. (2018). Preparation of 4-Deoxy-L-erythro-5-hexoseulose Uronic Acid (DEH) and Guluronic Acid Rich Alginate Using a Unique exo-Alginate Lyase from Thalassotalea crassostreae. Journal of Agricultural and Food Chemistry, 22.

22. Wang L, Li S, Yu W, Gong Q. Cloning, overexpression and characterization of a new oligoalginate lyase from a marine bacterium, Shewanella sp. Biotechnol Lett. 2014;159:77-86.

23. Wargacki AJ, Leonard E, Win MN, Regitsky DD, Santos CNS, Kim PB, et al. An Engineered Microbial Platform for Direct Biofuel Production from Brown Macroalgae. Science. 2012;335:308.

24. Xu F, Dong F, Wang P, Cao HY, Li CY, Li PY, et al. Novel Molecular Insights into the Catalytic Mechanism of Marine Bacterial Alginate Lyase AlyGC from Polysaccharide Lyase Family 6. JournalofBiological Chemistry. 2017;292:4457-68.

25. Yan J, Chen P, Zeng Y, Men Y, Mu S, Zhu Y, et al. The Characterization and Modification of a Novel Bifunctional and Robust Alginate Lyase Derived from Marinimicrobium sp. H1. marine drugs. 2019;17:545-58.

26. Yang J, Cui D, Ma S, Chen W, Chen D, Shen H. Characterization of a novel PL17 family alginate lyase with exolytic and endolytic cleavage activity from marine bacterium Microbulbifer sp. SH-1. Int J Biol Macromol. 2021;169:551-63.

27. Zhu B, Ni F, Sun Y, Ning L, Yao Z. Elucidation of degrading pattern and substrate recognition of a novel bifunctional alginate lyase from Flammeovirga sp. NJ-04 and its use for preparation alginate oligosaccharides. Biotechnol Biofuels. 2019;12:13.

28. Zhu B, Yin H. Alginate lyase: Review of major sources andclassification, properties, structure-function analysis and applications. Bioengineered. 2015;6(3):125-31.

\section{Figures}

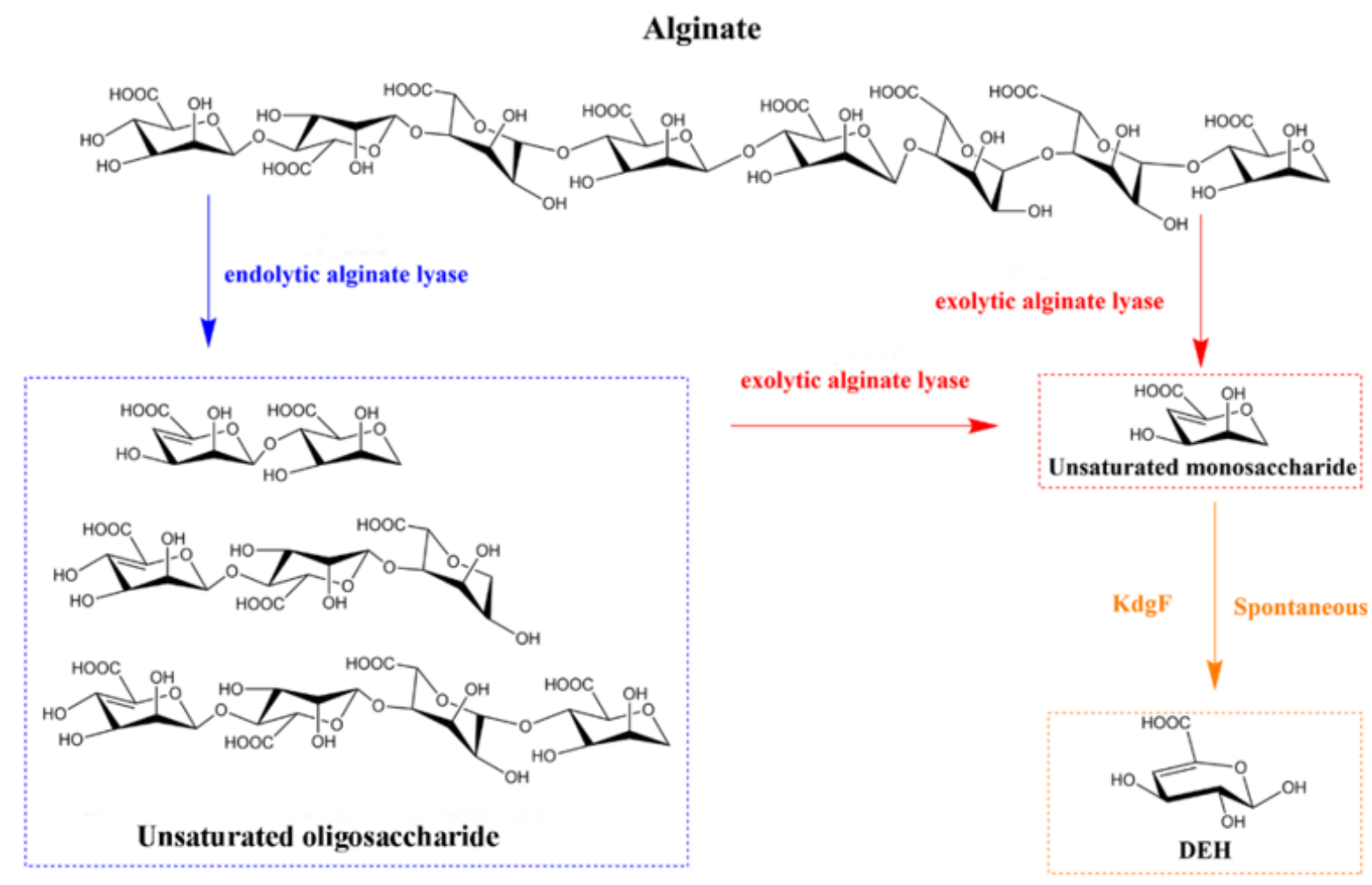

\section{Figure 1}

The schematic diagram of alginate metabolism. DEH represents4-Dexoy -L-erythron -5-hexoseulose Uronate. 

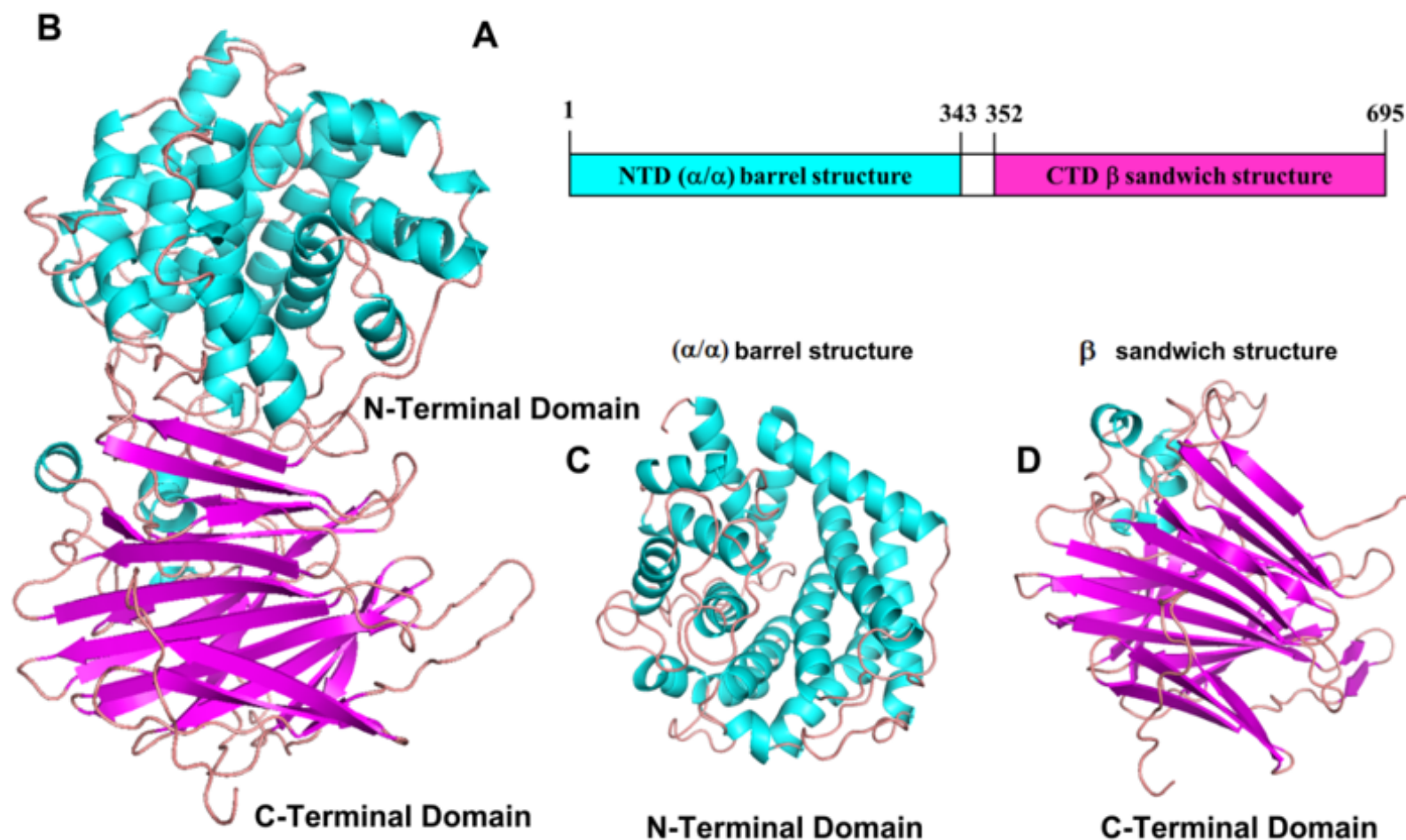

$(\alpha / \alpha)$ barrel structure

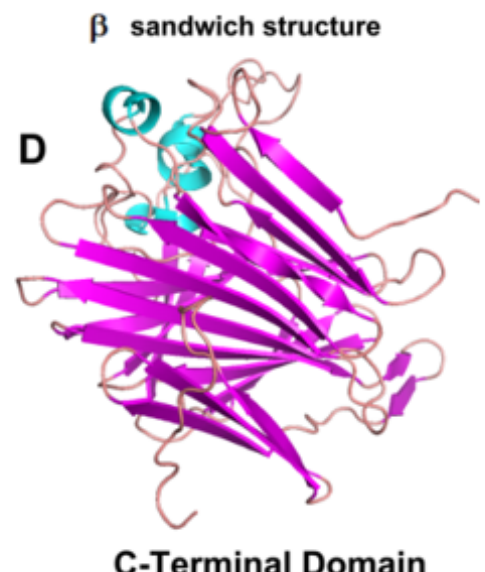

Figure 2

Modular organization of alginate lyase AlyPL17. (A) Module organization of AlyPL17. It contains an alginate lyase-like domain (AlyPL17N, Lys37-GIn265) and a Heparinase-like domain (AlyPL17-C, Arg357-Phe528); (B) The model structure of AlyPL17; (C) The model structure of AlyPL17N; (D) The model structure of AlyPL17C.

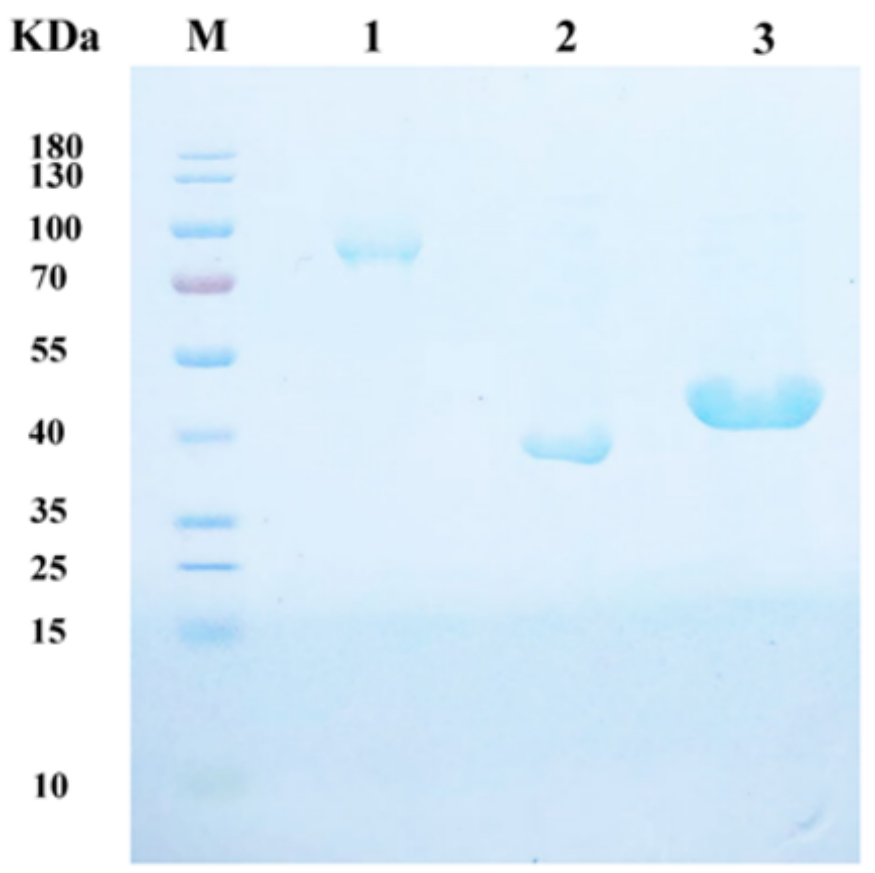

\section{Figure 3}

SDS-PAGE analysis of purified AlyPL17, AlyPL17-N and AlyPL17-C. Lane M, molecular weight markers; Lane 1, purified AlyPL17; Lane 2, purifiedAlyPL17-N; Lane 3, purified AlyPL17-C 
A

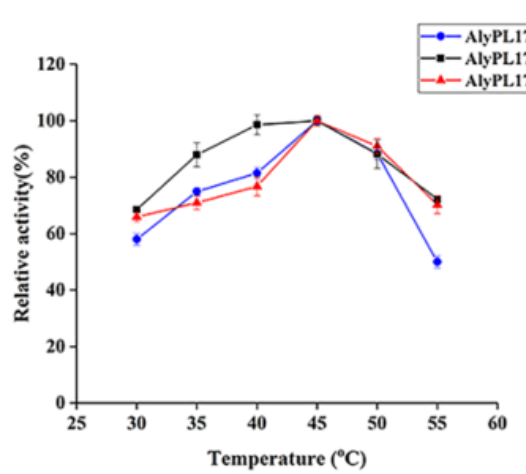

C

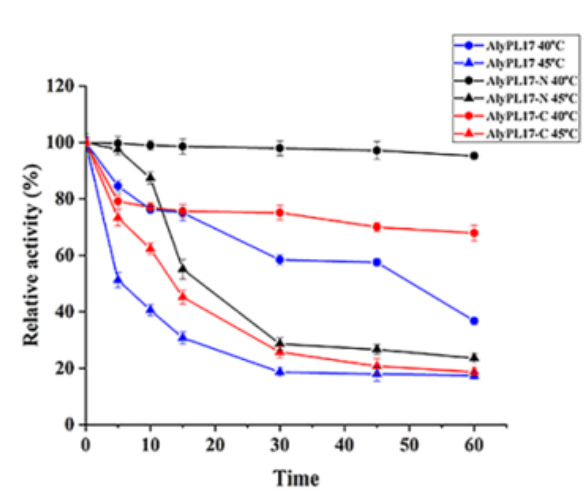

$\mathbf{E}$

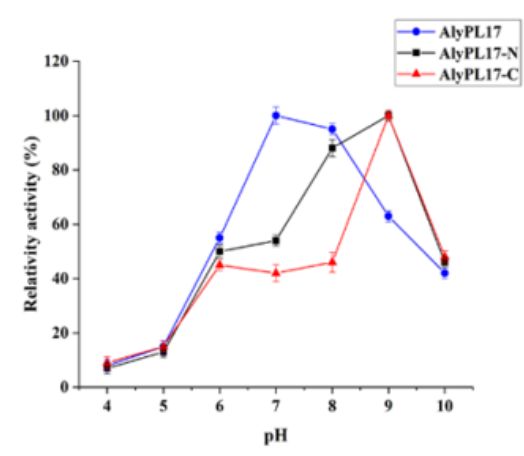

B

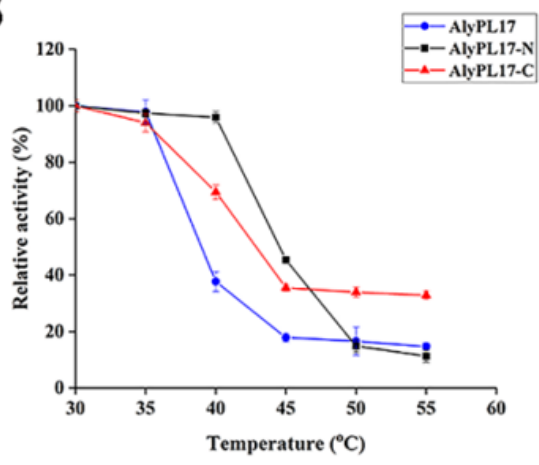

D

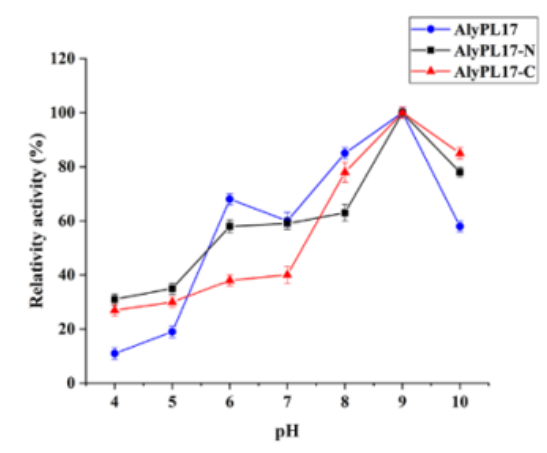

F

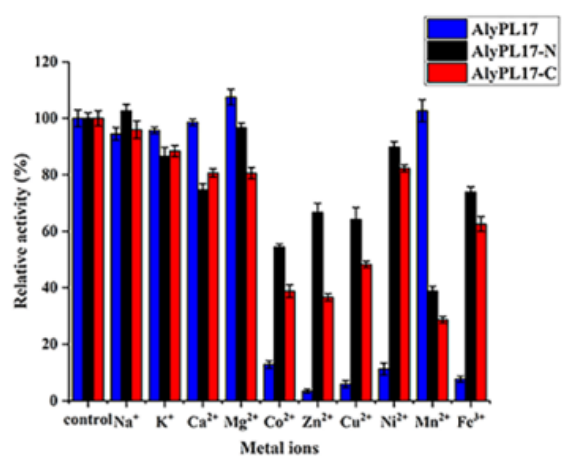

\section{Figure 4}

Biochemical characterization of AlyPL17 and its two truncated mutants. (A) The optimal temperature of AlyPL17 and its two truncated mutants. (B) The thermal stability of AlyPL17 and its two truncated mutants. (C) The thermal-induced denaturation of AlyPL17 and its two truncated mutants at $40 \mathrm{oC}$ and $45 \mathrm{oC}$. (D) The effect of pH on the enzymatic activity of AlyPL17 and its two truncated mutants. (E) The pH stability of AlyPL17 and its two truncated mutants. (F) The influence of metal ions of AlyPL17 and its two truncated mutants.
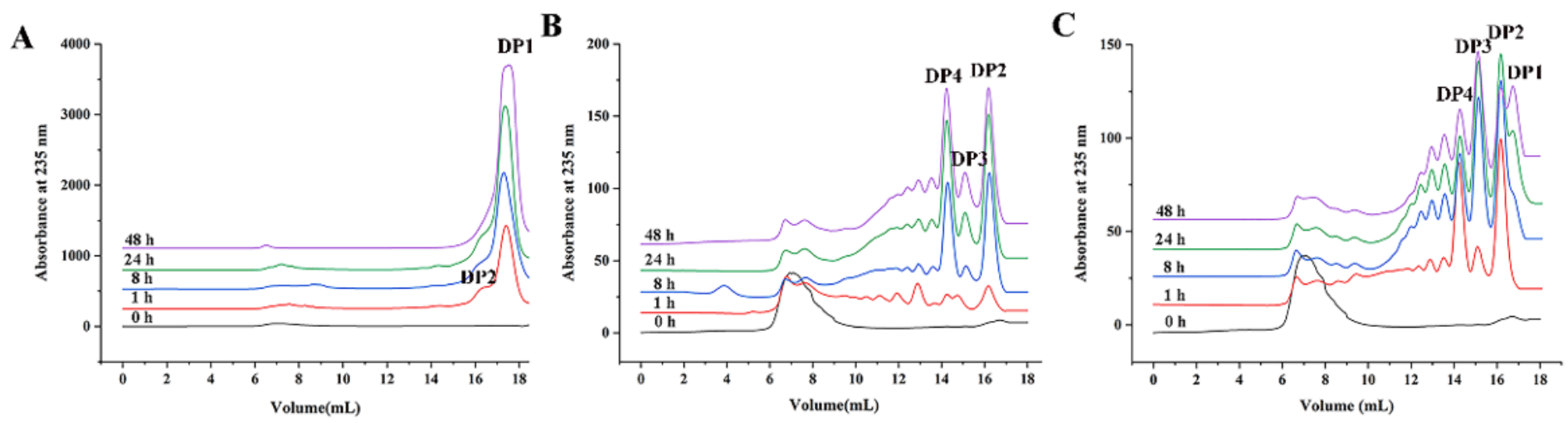

Figure 5 
FPLC analysis of the degradation products for $48 \mathrm{~h}$. (A) Degradation products generated by AlyPL17 (B) Degradation products generated by AlyPL17-N, (C) Degradation products generated by AlyPL17-C. The eluents were detected by measuring the absorbance at $235 \mathrm{~nm}$. The elution volumes of the unsaturated monomer, dimer, trimer, and tetramer are 17.35, 16.25, 15.23, and 14.38mL.
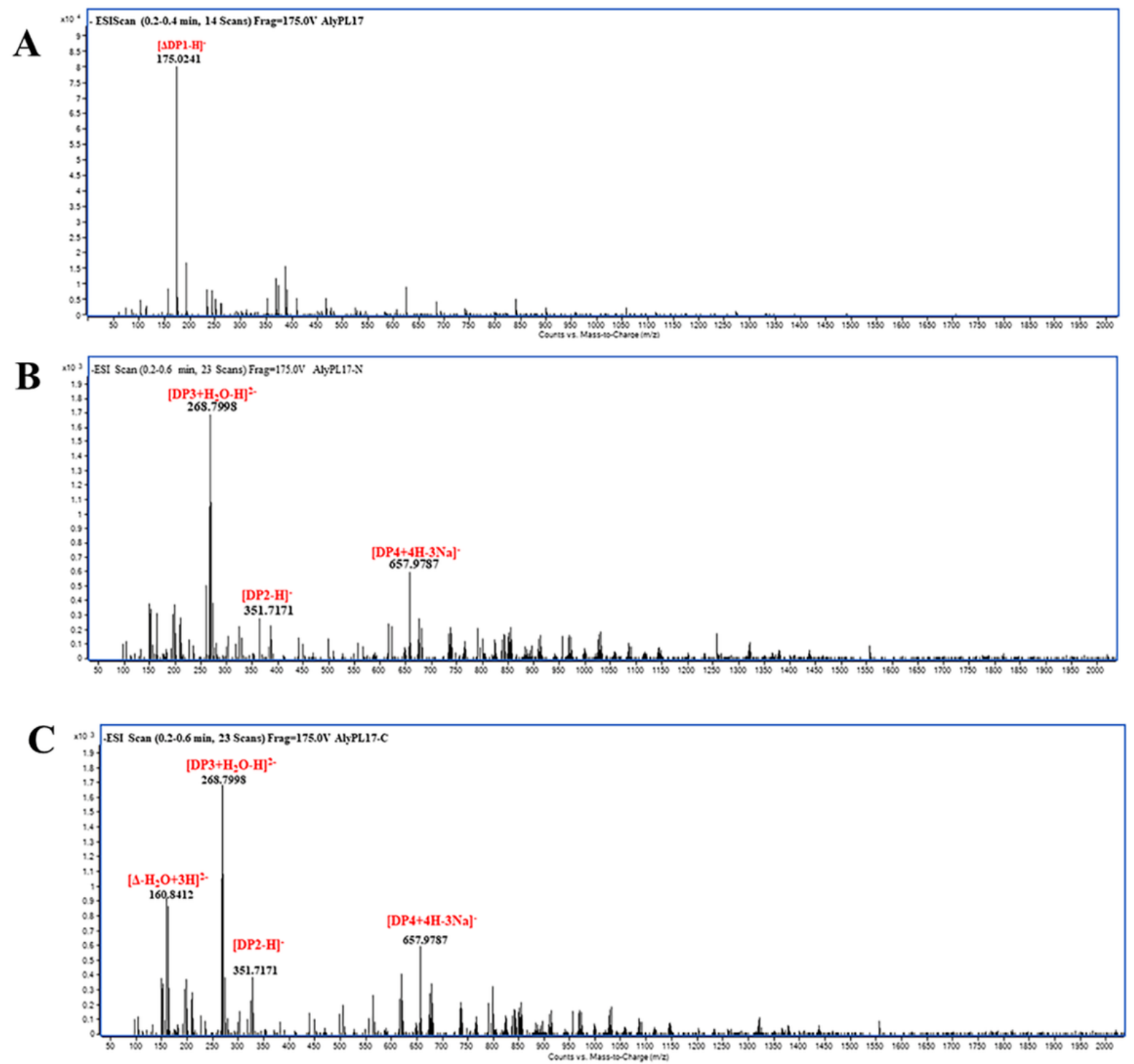

\section{Figure 6}

ESI-MS analysis for the degradation products of (A) AlyPL17, (B) AlyPL17-N, and (C) AlyPL17-C for $48 \mathrm{~h}$. 
A

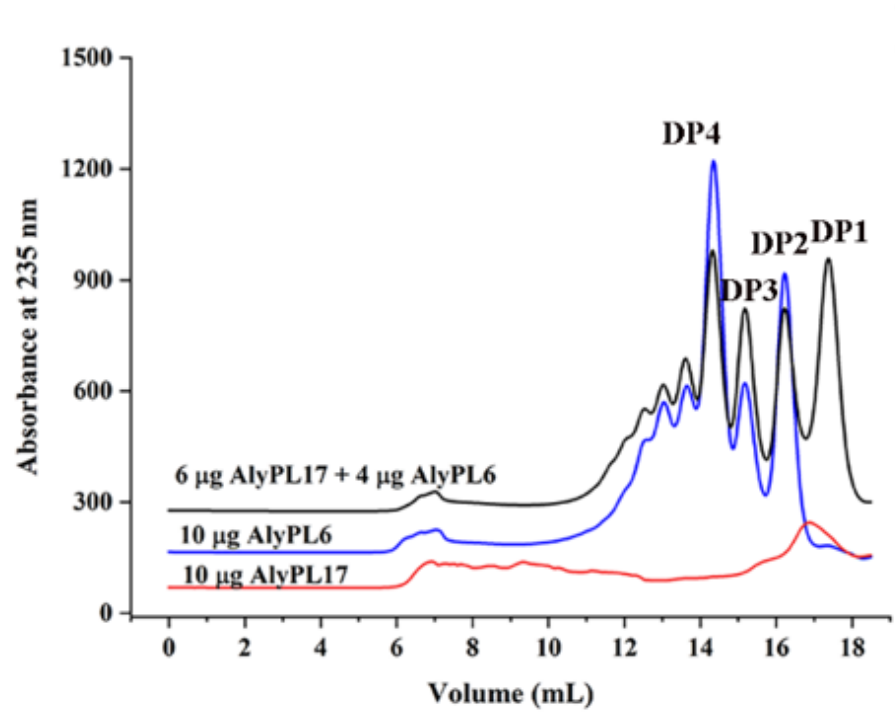

B

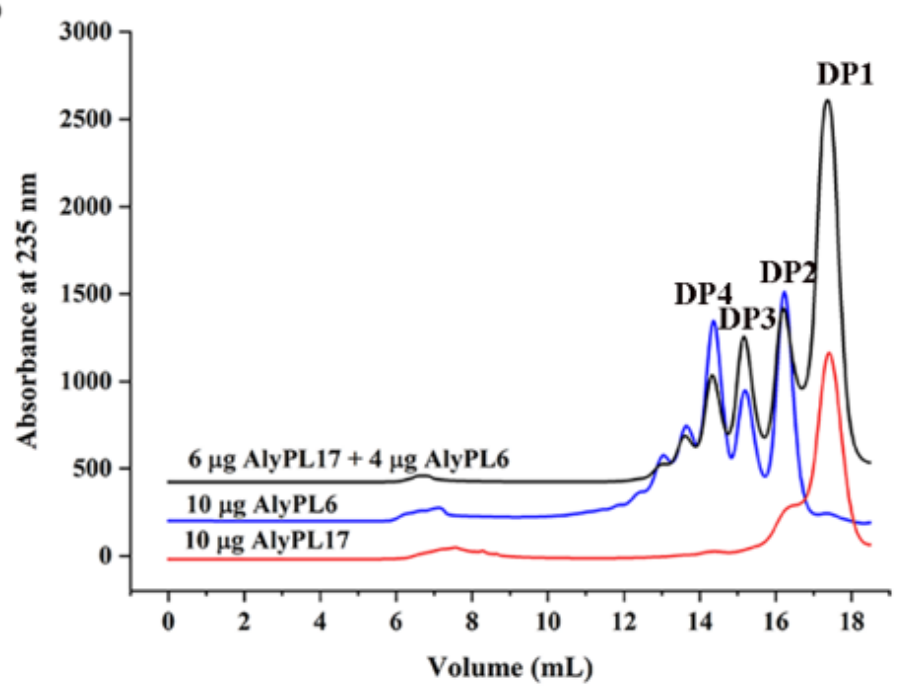

\section{Figure 7}

Analysis of the synergistic effect by FPLC. (A) Alginate was treated with a mixture $(10 \mathrm{mg})$ of $6 \mu \mathrm{g}$ AlyPL17 and $4 \mu \mathrm{g}$ AlyPL 6 at $45 \circ \mathrm{oC}$ for 10 min. By contrast, control was treated with only $10 \mu \mathrm{g}$ AlyPL6 or only $10 \mu \mathrm{g}$ AlyPL17 at the same conditions. (B) Alginate was treated with mixture, AlyPL6, or AlyPL17 at 45oC for $1 \mathrm{~h}$.

\section{Supplementary Files}

This is a list of supplementary files associated with this preprint. Click to download.

- Supplementaryinformation.docx 